\title{
Study on Normative Standards of Hard Asphalt for highway engineering in China
}

\author{
Jiang $\mathrm{Li}^{1,2^{*}}$, Shengjun $\mathrm{YU}^{1,2}$ and Dawei $\mathrm{LV}^{3}$ \\ ${ }^{1}$ Research Institute of Highway Ministry of Transport, Beijing, China, 100088 \\ ${ }^{2}$ Key Laboratory for Road Structure \& Material of Ministry of Transport, Beijing, China,100088; \\ ${ }^{3}$ Guangdong Road \& Bridge Construction Development Co., Ltd., Guangdong 511500, China;
}

\begin{abstract}
Hard asphalt has been applied and studied on Chinese highway asphalt pavement for nearly 20 years. Although it has excellent road performance, it has not been applied on a large scale. The main reason is that there is no clear technical standard and technical system for hard asphalt, which restricts the popularization and application of hard asphalt as a good material in the highway engineering. Therefore, it is urgent to formulate standards for hard asphalt products of highway engineering in China. In order to promote the large-scale application of hard asphalt for asphalt pavement in China, a draft definition of hard asphalt for highway use and a draft technical standard for engineering are proposed through a large number of tests and research analysis of various samples, drawing lessons from the current technical specifications and relevant international standards for hard asphalt.
\end{abstract}

\section{Introduction}

Hard asphalt is a kind of Low-grade asphalt, which is called high modulus asphalt or Low-grade asphalt in some countries or regions. It first appeared in France in the 1980s, and has been widely used in Britain, Finland, Netherlands and other European countries [1]. China began to research and apply hard asphalt in asphalt pavement engineering around 2000.

Research results and engineering practices at home and abroad show that [1-5,9-11]: hard asphalt and asphalt mixture pavement has good high temperature stability, water stability, anti-fatigue performance, especially its excellent high temperature stability, which can improve the rutting resistance of asphalt pavement in high temperature areas. The structural strength and service life of asphalt pavement can reduce the thickness of asphalt pavement and the cost of construction. It has good technical economy.

At present, the international technical standards for hard asphalt mainly include the hard asphalt paving Specifications in EN13924 of European Union commonly used in France and the hard asphalt paving Specifications in EN12591 in European Union commonly used.

At present, there is no technical standard for hard asphalt in China. Although the current "Technical Specifications for Construction of Highway Asphalt Pavement" (JTG F40-2004) refers to the technical requirements of 50\# and 30\# asphalt, there is no clear definition of hard asphalt and classification standard for hard asphalt. Influenced by the supply and demand relationship in China's market and the engineering application habits, the application of 50\# and 30\# asphalt is less, and there is no large-scale application. This is one of the main reasons that restrict the large-scale application of hard asphalt in China's highway Engineering. Therefore, it is urgent to formulate technical standards for Chinese hard asphalt.

Through a large number of experiments and research, this study puts forward the definition and the draft of technical standards of hard asphalt for highway engineering, which has an important technical support role in standardizing the quality of hard asphalt products, giving full play to the excellent road performance of hard asphalt and promoting its application.

\section{Materials and Methods}

\subsection{Materials}

In this study, 115 representative samples of hard asphalt for highway engineering from domestic asphalt producers (agents) were selected as samples to study the index system and standards of for highway engineering. Among them, 24 samples with penetration range of 10-20 (0.1 $\mathrm{mm}), 39$ asphalt samples with penetration range of 20-30 $(0.1 \mathrm{~mm}), 31$ asphalt samples with penetration range of $30-40(0.1 \mathrm{~mm})$ and 21 asphalt samples with penetration range of $40-50(0.1 \mathrm{~mm})$ are included.

\section{2. test methods}

According to the test method stipulated in "Technical Specifications for Construction of Highway Asphalt

\footnotetext{
* Corresponding author's e-mail: jiang.li@rioh.cn
} 
Pavement" (JTG F40-2004,), See below for specific methods.

\section{Results}

115 kinds of hard asphalt for for highway engineering are tested. The test results are as follows: Table 1-Table 5.

\subsection{Test results of hard asphalt for highway engineering with four penetration ranges}

Table1. Test results of samples of penetration range 10-20 of hard asphalt with for highway engineering $(0.1 \mathrm{~mm})$

\begin{tabular}{|c|c|c|c|c|c|c|c|}
\hline $\begin{array}{c}\text { Serial } \\
\text { number }\end{array}$ & $\begin{array}{c}\text { Penetration } \\
\left(25^{\circ} \mathrm{C}, 5 \mathrm{~s}, \mathbf{1 0 0 g}\right. \\
), \mathbf{0 . 1 m m}\end{array}$ & $\begin{array}{l}\text { Softening } \\
\text { point, }{ }^{\circ} \mathrm{C}\end{array}$ & $\begin{array}{c}\text { Kinetic } \\
\text { Viscosity } \\
/ 60^{\circ} \mathrm{C} \\
\text { Pa.s }\end{array}$ & $\begin{array}{c}\text { Kinetic } \\
\text { Viscosity } \\
/ \mathbf{1 3 5}^{\circ} \mathbf{C} \text {, Pa.s }\end{array}$ & $\begin{array}{l}\text { Ductilit } \\
\mathbf{y} / 25^{\circ} \mathrm{C}\end{array}$ & $\begin{array}{c}\text { Weight } \\
\text { change } \\
\text { by } \\
\text { TFOT, } \\
\%\end{array}$ & $\begin{array}{c}\text { Weight } \\
\text { change by } \\
\text { RTFOT, } \\
\%\end{array}$ \\
\hline 1 & 16 & 66.2 & 6100 & 2.72 & 12 & 0.10 & 0.09 \\
\hline 2 & 15 & 70.1 & 12600 & 3.21 & 14 & 0.09 & 0.12 \\
\hline 3 & 19 & 64.5 & 6760 & 2.32 & 25 & 0.12 & 0.21 \\
\hline 4 & 14 & 64.4 & 6420 & 1.74 & 11 & 0.37 & 0.29 \\
\hline 5 & 17 & 64.2 & 6388 & 1.70 & 20 & 0.28 & 0.17 \\
\hline 6 & 18 & 64.1 & 6391 & 1.72 & 19 & 0.19 & 0.21 \\
\hline 7 & 18 & 64.0 & 6401 & 1.70 & 19 & 0.22 & 0.22 \\
\hline 8 & 17 & 64.1 & 6400 & 1.71 & 12 & 0.10 & 0.30 \\
\hline 9 & 16 & 64.1 & 5170 & 1.79 & 9 & 0.10 & 0.11 \\
\hline 10 & 18 & 65.0 & 6231 & 1.90 & 12 & 0.19 & 0.21 \\
\hline 11 & 19 & 63.7 & 3421 & 1.92 & 17 & 0.22 & 0.21 \\
\hline 12 & 16 & 64.7 & 3879 & 1.32 & 27 & 0.34 & 0.32 \\
\hline 13 & 13 & 65.9 & 4952 & 1.48 & 6 & 0.44 & 0.29 \\
\hline 14 & 15 & 64.8 & 4003 & 1.32 & 20 & 0.12 & 0.09 \\
\hline 15 & 13 & 65.4 & 5046 & 1.45 & 6 & 0.22 & 0.19 \\
\hline 16 & 20 & 62.5 & 2634 & 1.09 & 21 & 0.17 & 0.23 \\
\hline 17 & 17 & 63.5 & 3054 & 1.25 & 19 & 0.56 & 0.39 \\
\hline 18 & 15 & 63.9 & 3425 & 1.31 & 12 & 0.23 & 0.37 \\
\hline 19 & 18 & 62.9 & 3031 & 1.23 & 11 & 0.23 & 0.22 \\
\hline 20 & 14 & 63.5 & 3378 & 1.32 & 27 & 0.46 & 0.21 \\
\hline 21 & 17 & 63.5 & 3390 & 1.20 & 10 & 0.17 & 0.31 \\
\hline 22 & 13 & 64.9 & 4357 & 1.75 & 9 & 0.09 & 0.12 \\
\hline 23 & 19 & 62.7 & 2548 & 0.95 & 21 & 0.23 & 0.07 \\
\hline 24 & 16 & 64.1 & 3812 & 1.81 & 17 & 0.16 & 0.17 \\
\hline AVG & 16.38 & 64.45 & 4991.29 & 1.66 & 15.67 & 0.23 & 0.21 \\
\hline Max & 20 & 70.1 & 12600 & 3.21 & 27 & 0.56 & 0.39 \\
\hline Min & 13 & 62.5 & 2548 & 0.95 & 6 & 0.09 & 0.07 \\
\hline
\end{tabular}

Table 2. Test results of samples of penetration range 20-30 of hard asphalt with for highway engineering $(0.1 \mathrm{~mm})$

\begin{tabular}{|c|c|c|c|c|c|c|c|}
\hline $\begin{array}{c}\text { Serial } \\
\text { number }\end{array}$ & $\begin{array}{c}\text { Penetration } \\
\left(25^{\circ} \mathrm{C}, 5 \mathrm{~s}, \mathbf{1 0 0 \mathrm { g }}\right. \\
), \mathbf{0 . 1 \mathrm { mm }}\end{array}$ & $\begin{array}{l}\text { Softening } \\
\text { point, }{ }^{\circ} \mathrm{C}\end{array}$ & $\begin{array}{c}\text { Kinetic } \\
\text { Viscosity } \\
/ 60^{\circ} \mathrm{C} \\
\text { Pa.s }\end{array}$ & $\begin{array}{c}\text { Kinetic } \\
\text { Viscosity } \\
/ \mathbf{1 3 5}^{\circ} \mathbf{C}, \text { Pa.s }\end{array}$ & $\begin{array}{l}\text { Ductilit } \\
\mathbf{y} / 25^{\circ} \mathrm{C}\end{array}$ & $\begin{array}{c}\text { Weight } \\
\text { change } \\
\text { by } \\
\text { TFOT, } \\
\%\end{array}$ & $\begin{array}{c}\text { Weight } \\
\text { change by } \\
\text { RTFOT, } \\
\%\end{array}$ \\
\hline 1 & 23 & 61.2 & 2460 & 1.73 & 45 & 0.32 & 0.22 \\
\hline 2 & 25 & 62.1 & 2490 & 1.74 & 54 & 0.44 & 0.46 \\
\hline 3 & 24 & 61.8 & 2436 & 1.73 & 49 & 0.47 & 0.27 \\
\hline 4 & 25 & 59.7 & 1900 & 1.57 & 53 & 0.77 & 0.56 \\
\hline 5 & 21 & 63.5 & 3130 & 1.81 & 31 & 0.62 & 0.43 \\
\hline 6 & 22 & 60.2 & 1710 & 1.32 & 31 & 0.45 & 0.54 \\
\hline 7 & 21 & 60.4 & 2010 & 1.40 & 19 & 0.51 & 0.47 \\
\hline 8 & 22 & 62.5 & 5001 & 1.64 & 42 & 0.51 & 0.47 \\
\hline 9 & 21 & 62.6 & 5013 & 1.65 & 32 & 0.44 & 0.56 \\
\hline 10 & 22 & 62.6 & 5021 & 1.63 & 29 & 0.35 & 0.27 \\
\hline 11 & 20 & 62.5 & 2634 & 1.09 & 17 & 0.37 & 0.33 \\
\hline 12 & 25 & 60.3 & 1329 & 0.76 & 49 & 0.43 & 0.41 \\
\hline 13 & 29 & 60.5 & 2180 & 1.62 & 57 & 0.44 & 0.45 \\
\hline 14 & 30 & 60.3 & 1760 & 1.47 & 67 & 0.52 & 0.39 \\
\hline
\end{tabular}




\begin{tabular}{|c|c|c|c|c|c|c|c|}
\hline 15 & 29 & 60.5 & 2000 & 1.61 & 54 & 0.33 & 0.27 \\
\hline 16 & 26 & 59.7 & 1750 & 1.26 & 52 & 0.27 & 0.32 \\
\hline 17 & 26 & 60.0 & 1875 & 1.42 & 70 & 0.33 & 0.21 \\
\hline 18 & 30 & 57.4 & 1070 & 1.06 & 54 & 0.56 & 0.51 \\
\hline 19 & 28 & 58.9 & 1420 & 1.19 & 53 & 0.51 & 0.53 \\
\hline 20 & 30 & 60.9 & 2310 & 1.21 & 52 & 0.47 & 0.45 \\
\hline 21 & 25 & 62.0 & 2347 & 1.31 & 47 & 0.38 & 0.36 \\
\hline 22 & 22 & 60.7 & 2334 & 1.26 & 39 & 0.62 & 0.61 \\
\hline 23 & 22 & 60.7 & 2321 & 1.24 & 32 & 0.55 & 0.45 \\
\hline 24 & 22 & 60.8 & 2338 & 1.26 & 28 & 0.23 & 0.21 \\
\hline 25 & 25 & 59.2 & 1980 & 1.17 & 51 & 0.19 & 0.17 \\
\hline 26 & 26 & 59.4 & 1990 & 1.18 & 54 & 0.44 & 0.45 \\
\hline 27 & 26 & 59.6 & 2013 & 1.25 & 49 & 0.42 & 0.41 \\
\hline 28 & 27 & 59.4 & 2010 & 1.24 & 61 & 0.37 & 0.39 \\
\hline 29 & 25 & 59.7 & 2015 & 1.23 & 52 & 0.45 & 0.42 \\
\hline 30 & 26 & 62.8 & 2464 & 1.10 & 51 & 0.24 & 0.37 \\
\hline 31 & 27 & 62.4 & 2297 & 1.05 & 56 & 0.19 & 0.10 \\
\hline 32 & 29 & 61.7 & 2132 & 0.99 & 49 & 0.27 & 0.27 \\
\hline 33 & 29 & 58.4 & 1035 & 0.69 & 43 & 0.26 & 0.25 \\
\hline 34 & 30 & 58.1 & 686 & 0.53 & 60 & 0.33 & 0.31 \\
\hline 35 & 26 & 59.8 & 1519 & 0.71 & 47 & 0.37 & 0.41 \\
\hline 36 & 27 & $\begin{array}{c}58.9 \\
740.9\end{array}$ & 740 & 0.58 & 70 & 0.31 & 0.29 \\
\hline 37 & 29 & 58.9 & 1293 & 0.79 & 71 & 0.47 & 0.41 \\
\hline 38 & 27 & 59.4 & 1363 & 0.85 & 52 & 0.29 & 0.24 \\
\hline 39 & 25 & 61.9 & 1647 & 0.83 & 42 & 0.51 & 0.46 \\
\hline AVG & 2.42 & 33.17 & 631.03 & 0.27 & 9.89 & 0.10 & 0.10 \\
\hline Max & 30 & 740.9 & 5021 & 1.81 & 71 & 0.77 & 0.61 \\
\hline Min & 20 & 57.4 & 686 & 0.53 & 17 & 0.19 & 0.1 \\
\hline
\end{tabular}

Table 3. Test results of samples of penetration range 30-40 of hard asphalt with for highway engineering $(0.1 \mathrm{~mm})$

\begin{tabular}{|c|c|c|c|c|c|c|c|}
\hline $\begin{array}{c}\text { Serial } \\
\text { number }\end{array}$ & $\begin{array}{c}\text { Penetration } \\
\left(25^{\circ} \mathrm{C}, 5 \mathrm{~s}, 100 \mathrm{~g}\right. \\
\quad, \mathbf{0 . 1 m m}\end{array}$ & $\begin{array}{l}\text { Softening } \\
\text { point, }{ }^{\circ} \mathrm{C}\end{array}$ & $\begin{array}{c}\text { Kinetic } \\
\text { Viscosity } \\
/ 60^{\circ} \mathrm{C} \\
\text { Pa.s }\end{array}$ & $\begin{array}{c}\text { Kinetic } \\
\text { Viscosity } \\
/ \mathbf{1 3 5}^{\circ} \mathrm{C}, \text { Pa.s }\end{array}$ & $\begin{array}{l}\text { Ductilit } \\
\mathrm{y} / 25^{\circ} \mathrm{C}\end{array}$ & $\begin{array}{c}\text { Weight } \\
\text { change } \\
\text { by } \\
\text { TFOT, } \\
\%\end{array}$ & $\begin{array}{c}\text { Weight } \\
\text { change by } \\
\text { RTFOT, } \\
\%\end{array}$ \\
\hline 1 & 30 & 60.3 & 1760 & 1.47 & 64 & 0.42 & 0.42 \\
\hline 2 & 31 & 59.5 & 1630 & 1.44 & 52 & 0.54 & 0.49 \\
\hline 3 & 34 & 57.1 & 1240 & 1.33 & 66 & 0.67 & 0.61 \\
\hline 4 & 30 & 57.4 & 1070 & 1.06 & 30 & 0.77 & 0.79 \\
\hline 5 & 32 & 57.2 & 1010 & 1.02 & 56 & 0.72 & 0.64 \\
\hline 6 & 30 & 60.9 & 2310 & 1.21 & 78 & 0.45 & 0.53 \\
\hline 7 & 32 & 60.1 & 1690 & 0.88 & 80 & 0.61 & 0.67 \\
\hline 8 & 31 & 62.2 & 2479 & 1.08 & 75 & 0.51 & 0.41 \\
\hline 9 & 32 & 56.8 & 423 & 0.43 & 75 & 0.64 & 0.56 \\
\hline 10 & 30 & 58.1 & 686 & 0.53 & 50 & 0.35 & 0.53 \\
\hline 11 & 35 & 56.8 & 785 & 0.58 & $>100$ & 0.37 & 0.42 \\
\hline 12 & 31 & 58.1 & 1101 & 0.70 & 89 & 0.43 & 0.41 \\
\hline 13 & 35 & 56.5 & 1320 & 1.26 & 90 & 0.47 & 0.49 \\
\hline 14 & 40 & 56.5 & 1060 & 1.15 & 80 & 0.22 & 0.21 \\
\hline 15 & 35 & 57.1 & 1140 & 1.22 & 76 & 0.33 & 0.35 \\
\hline 16 & 38 & 59.6 & 980 & 1.13 & 57 & 0.57 & 0.61 \\
\hline 17 & 32 & 58.4 & 1250 & 1.08 & 88 & 0.33 & 0.21 \\
\hline 18 & 38 & 56.0 & 925 & 1.00 & 90 & 0.66 & 0.44 \\
\hline 19 & 38 & 55.4 & 815 & 0.89 & $>100$ & 0.51 & 0.57 \\
\hline 20 & 39 & 54.8 & 756 & 0.86 & 89 & 0.47 & 0.42 \\
\hline 21 & 37 & 54.8 & 791 & 0.74 & 54 & 0.48 & 0.44 \\
\hline 22 & 40 & 53.5 & 752 & 0.70 & 85 & 0.72 & 0.62 \\
\hline 23 & 39 & 53.0 & 732 & 0.68 & $>100$ & 0.55 & 0.57 \\
\hline 24 & 39 & 53.1 & 745 & 0.70 & 80 & 0.23 & 0.33 \\
\hline 25 & 35 & 57.9 & 1100 & 0.95 & 77 & 0.89 & 0.77 \\
\hline 26 & 40 & 55.9 & 848 & 0.80 & 80 & 0.44 & 0.41 \\
\hline 27 & 38 & 56.8 & 860 & 0.64 & 59 & 0.42 & 0.39 \\
\hline 28 & 40 & 55.9 & 604 & 0.58 & 79 & 0.57 & 0.42 \\
\hline
\end{tabular}




\begin{tabular}{cccccccc}
\hline 29 & 39 & 54.2 & 403 & 0.46 & 90 & 0.25 & 0.27 \\
30 & 38 & 55.6 & 646 & 0.54 & 92 & 0.44 & 0.41 \\
31 & 40 & 55.7 & 574 & 0.51 & 73 & 0.39 & 0.32 \\
AVG & 35.42 & 56.94 & 1047.90 & 0.89 & 73.36 & 0.50 & 0.48 \\
Max & 40 & 62.2 & 2479 & 1.47 & 92 & 0.89 & 0.79 \\
Min & 30 & 53 & 403 & 0.43 & 30 & 0.22 & 0.21 \\
\hline
\end{tabular}

Table 4. Test results of samples of penetration range 40-50of hard asphalt with for highway engineering $(0.1 \mathrm{~mm})$

\begin{tabular}{|c|c|c|c|c|c|c|c|}
\hline $\begin{array}{c}\text { Serial } \\
\text { number }\end{array}$ & $\begin{array}{c}\text { Penetration } \\
\left(25^{\circ} \mathrm{C}, 5 \mathrm{~s}, 100 \mathrm{~g}\right. \\
), 0.1 \mathrm{~mm}\end{array}$ & $\begin{array}{l}\text { Softening } \\
\text { point, }{ }^{\circ} \mathrm{C}\end{array}$ & $\begin{array}{c}\text { Kinetic } \\
\text { Viscosity } \\
/ 60^{\circ} \mathrm{C} \\
\text { Pa.s }\end{array}$ & $\begin{array}{c}\text { Kinetic } \\
\text { Viscosity } \\
/ \text { 135 }^{\circ} \mathrm{C}, \text { Pa.s }\end{array}$ & $\begin{array}{l}\text { Ductilit } \\
\mathrm{y} / 25^{\circ} \mathrm{C}\end{array}$ & $\begin{array}{c}\text { Weight } \\
\text { change } \\
\text { by } \\
\text { TFOT, } \\
\%\end{array}$ & $\begin{array}{c}\text { Weight } \\
\text { change by } \\
\text { RTFOT, } \\
\%\end{array}$ \\
\hline 1 & 40 & 56.5 & 1060 & 1.15 & $>100$ & 0.52 & 0.49 \\
\hline 2 & 41 & 54.9 & 844 & 1.10 & 90 & 0.34 & 0.32 \\
\hline 3 & 41 & 54.3 & 751 & 0.81 & 87 & 0.68 & 0.69 \\
\hline 4 & 40 & 53.5 & 752 & 0.70 & $>100$ & 0.27 & 0.33 \\
\hline 5 & 41 & 52.9 & 712 & 0.69 & $>100$ & 0.73 & 0.76 \\
\hline 6 & 40 & 55.9 & 848 & 0.80 & $>100$ & 0.48 & 0.55 \\
\hline 7 & 42 & 53.4 & 710 & 0.70 & $>100$ & 0.63 & 0.39 \\
\hline 8 & 43 & 53.3 & 702 & 0.71 & 53 & 0.51 & 0.49 \\
\hline 9 & 43 & 53.4 & 702 & 0.72 & $>100$ & 0.48 & 0.48 \\
\hline 10 & 42 & 56.0 & 670 & 0.59 & $>100$ & 0.39 & 0.32 \\
\hline 11 & 42 & 56.4 & 623 & 0.60 & 80 & 0.31 & 0.31 \\
\hline 12 & 41 & 55.7 & 587 & 0.48 & 93 & 0.44 & 0.45 \\
\hline 13 & 40 & 55.9 & 604 & 0.58 & 87 & 0.67 & 0.66 \\
\hline 14 & 42 & 52.6 & 469 & 0.47 & 99 & 0.23 & 0.33 \\
\hline 15 & 42 & 53.0 & 301 & 0.39 & $>100$ & 0.46 & 0.45 \\
\hline 16 & 43 & 52.2 & 286 & 0.32 & $>100$ & 0.44 & 0.42 \\
\hline 17 & 42 & 53.1 & 302 & 0.35 & 85 & 0.41 & 0.48 \\
\hline 18 & 42 & 56.0 & 514 & 0.49 & 86 & 0.39 & 0.31 \\
\hline 19 & 40 & 55.7 & 574 & 0.51 & 90 & 0.29 & 0.30 \\
\hline 20 & 43 & 55.4 & 524 & 0.50 & $>100$ & 0.32 & 0.27 \\
\hline 21 & 41 & 56.2 & 683 & 0.55 & $>100$ & 0.27 & 0.22 \\
\hline AVG & 41.48 & 54.59 & 629.43 & 0.63 & 85.00 & 0.44 & 0.43 \\
\hline Max & 43 & 56.5 & 1060 & 1.15 & 99 & 0.73 & 0.76 \\
\hline Min & 40 & 52.2 & 286 & 0.32 & 53 & 0.23 & 0.22 \\
\hline
\end{tabular}

\subsection{Tracking test in the production of hard asphalt for highway engineering by major asphalt producers}

At the same time, the indexes of penetration, softening point and kinetic viscosity of hard asphalt produced by major domestic asphalt producers were tested and analyzed. The results of the test and analysis are shown in Fig.1 and Fig.2.

The test results show that when the penetration $(25 \mathrm{C}$, $5 \mathrm{~s}, 100 \mathrm{~g})$ is less than $50(1 / 10 \mathrm{~mm})$, the kinetic viscosity $\left(60^{\circ} \mathrm{C}\right)$ is above $300 \mathrm{~Pa}$. s,the softening point is above $50{ }^{\circ} \mathrm{C}$. When the penetration is lower, the increase of kinetic viscosity is larger, which is consistent with the test results of the samples collected in the laboratory.

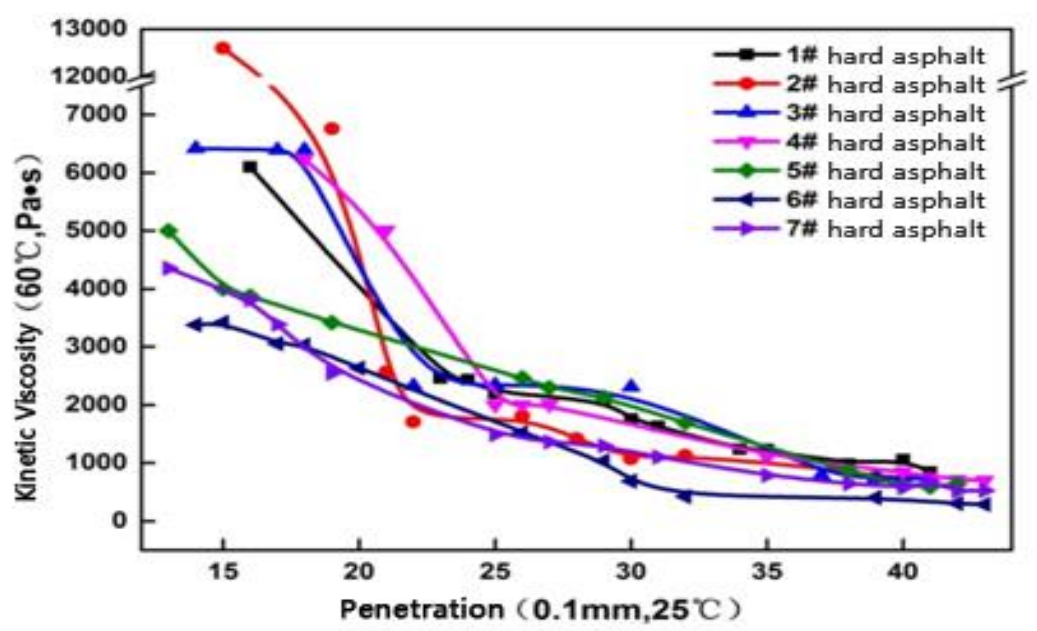

Figure1. Variation of kinetic viscosity with penetration 


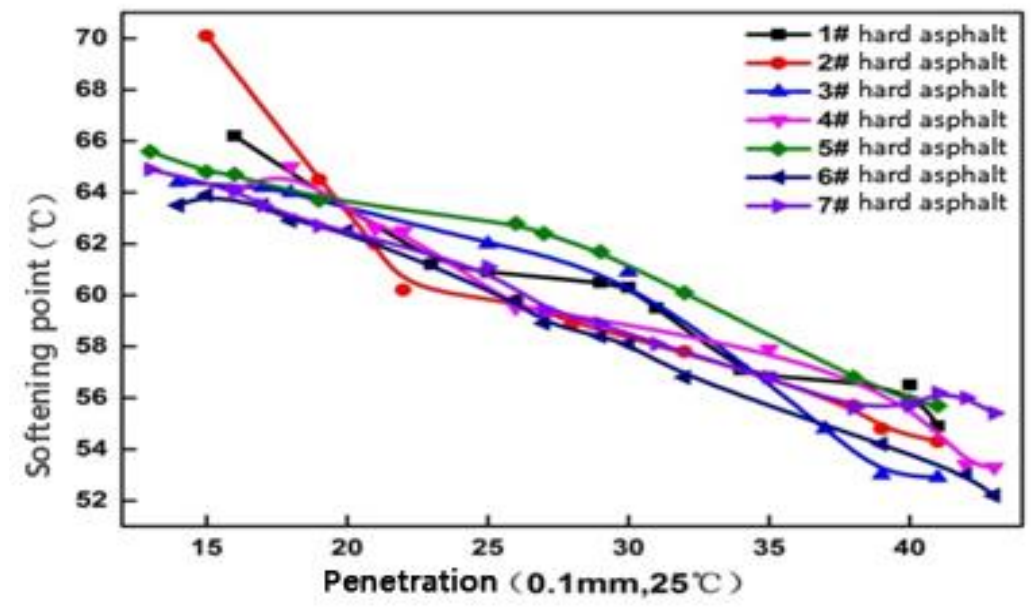

Figure2. The Variation of softening point with penetration

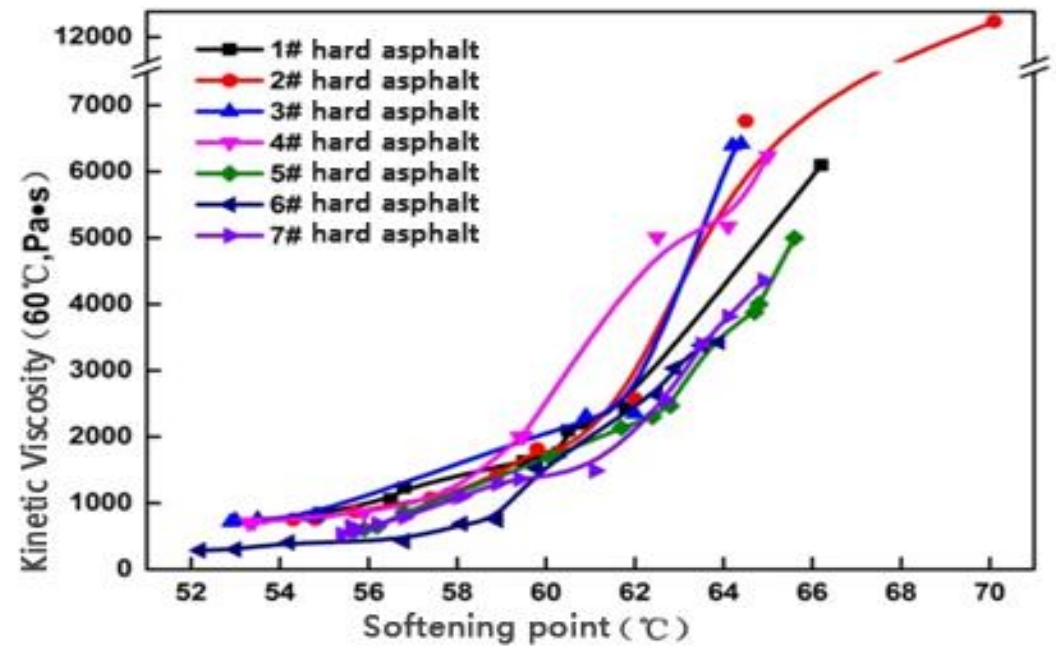

Figure3. Variation of kinetic viscosity with softening point

\subsection{Four-component comparison test of road hard asphalt and other road asphalts}

The four-component test results of hard asphalt and other asphalts are shown in Table 5.

Table 5. Four-component test results of hard asphalt and 90\# and 70\# Asphalts

\begin{tabular}{ccccc}
\hline Samples & $\begin{array}{c}\text { Saturation } \\
\text { constituent, } \%\end{array}$ & $\begin{array}{c}\text { aromatics } \\
\text { constituent, } \%\end{array}$ & $\begin{array}{c}\text { Resin } \\
\text { constituent, \% }\end{array}$ & $\begin{array}{c}\text { asphaltene } \\
\text { constituent, } \%\end{array}$ \\
\hline 90\#asphalt & 12.3 & 52.1 & 27.5 & 8.1 \\
70\# asphalt & 11.7 & 50.1 & 27.3 & 10.9 \\
50\# asphalt & 7.9 & 47.9 & 31.5 & 12.7 \\
30\# asphalt & 5.1 & 41.2 & 37.6 & 16.1 \\
\hline
\end{tabular}

The test results show that the content of asphaltene in road hard asphalt is higher than that in 90\# and 70\# asphalt, which shows that hard asphalt mixture has higher cohesion $\mathrm{C}$.

\section{Discussion}

\subsection{Definition of road hard asphalt for highway engineering}

\subsubsection{Definition of hard asphalt for highway} engineering
Definition: asphalt with penetration less than $50(0.1 \mathrm{~mm})$ for each structural layer of asphalt pavement is produced with petroleum as raw material and appropriate related technology.

Hard asphalt is also used in other professions such as petrochemical, municipal and other industries, but they are different from the technical indicators and requirements of hard asphalt in highway engineering, so it should be called "road hard asphalt" in highway engineering to highlight its road performance characteristics. 


\subsubsection{Grading label of hard asphalt for highway engineering (draft recommendations)}

Grading labels of hard asphalt for highway engineering are Classified into 15\#, 25\#, 35\# and 45 \#according to the penetration.

Compared with "Technical Specifications for Construction of Highway Asphalt Pavement" (JTG F40-2004), for the penetration of hard asphalt is lower, so this study proposes the Grading label of hard asphalt for highway engineering should be done with the range of penetration 10, and from small to large, it is Classified into four grades such as $15 \#, 25 \# 、 35 \# 、 45 \#$.

\section{2. requirements of hard asphalt for highway engineering}

According to the test results and engineering application requirements, this study proposes the following draft technical standards for hard asphalt for highway engineering, which are divided into general technical requirements and main technical requirements, such as Table 6 and Table 7.

\subsubsection{General requirements}

It is suggested that the general requirements of hard asphalt for highway engineering should meet the requirements of Table 6

Table 6. General requirements for hard asphalt for highway engineering

\begin{tabular}{|c|c|}
\hline Technical Indicators & Control Value of Each Grading label \\
\hline & $35 \#$ \\
\hline Ductility $/ 25^{\circ} \mathrm{C}, \mathrm{cm}$ & No more than the production plant internal control value \\
\hline Kinetic Viscosity $/ 135^{\circ} \mathrm{C}$, Pa.s & No more than the production plant internal control value \\
\hline Density $/ 15^{\circ} \mathrm{C}, \mathrm{g} . \mathrm{cm}-3$ & No more than the production plant internal control value \\
\hline $\begin{array}{c}\text { Residual ductility after TFOT (or } \\
\text { RTFOT) } / 25^{\circ} \mathrm{C}, \mathrm{cm}\end{array}$ & No more than the production plant internal control value \\
\hline
\end{tabular}

Note 1: The internal control value of each index is indicated in the relevant technical data of the production plant.

Note 2: Requirements for internal control values between the same and different batches can be agreed by both suppliers and consumers.

Note 3: TFOT (or RTFOT) is the thin-film oven test (or the thin-film rotary film heating test).

\subsubsection{Main technical requirements}

It is suggested that the main technical requirements of hard asphalt for highway engineering should meet the requirements of Table 7 .

Table 7. Main technical requirements of hard asphalt for highway engineering

\begin{tabular}{ccccc}
\hline Technical Indicators & \multicolumn{4}{c}{ Control Value of Each Grading label } \\
\hline & $15 \#$ & $25 \#$ & $35 \#$ & $45 \#$ \\
Penetration $\left(25^{\circ} \mathrm{C}, 5 \mathrm{~s}, 100 \mathrm{~g}\right), 0.1 \mathrm{~mm}$ & $10 \sim 20$ & $20 \sim 30$ & $30 \sim 40$ & $40 \sim 50$ \\
Softening point $(\mathrm{R} \& \mathrm{~B}),{ }^{\circ} \mathrm{C}$ & $\geq 60.0$ & $\geq 57.0$ & $\geq 55.0$ & $\geq 50.0$ \\
Kinetic Viscosity $/ 60^{\circ} \mathrm{C}, \mathrm{Pa} . \mathrm{s}$ & $\geq 2000$ & $\geq 1000$ & $\geq 500$ & $\geq 300$ \\
solubility, $\%$ & & $\geq 99.5$ & \\
Opening flash point, ${ }^{\circ} \mathrm{C}$ & & $\geq 260$ & \\
Wax content, $\%$ & & $\leq 3.0$ & \\
After TFOT $\quad$ Weight change, $\%$ & & $-0.6 \sim+0.6$ & \\
(or $\quad$ Residual & & & & \\
RTFOT $\quad$ penetration & & & & \\
\end{tabular}

\subsection{Analysis and basis of standard suggestions}

Based on the test results, this study analyzed and drew lessons from the relevant concepts and Technical indexes of "Technical Specifications for Construction of Highway Asphalt Pavement" (JTG F40-2004), European Union Standard EN13924 and European Union Standard EN12591, then put forward the recommended standards in this study.

\subsubsection{Ductility/25 ${ }^{\circ} \mathrm{C}$}

With a long-term study, it is found that the ductility index $\left(15 / 25^{\circ} \mathrm{C}\right)$ of asphalt can effectively control the content and uniformity of asphalt impurities, but the ductility index value also have poor correlation with the performance of mixtures in a certain range.

The users and researchers pay more attention to the high-temperature stability of hard asphalt, and the advantages of hard asphalt are mainly due to its high-temperature stability. The proposed standard abandons the low temperature ductility index of $15^{\circ} \mathrm{C}$, but in order to ensure the stability and reliability of the source 
and processing technology of hard asphalt for highway engineering, the ductility index of $25^{\circ} \mathrm{C}$ is still retained, and the index requirement does not exceed the internal control value of the production plant.

\subsubsection{Kinetic Viscosity $/ 135^{\circ} \mathrm{C}$}

This technical index is designed to facilitate the habits of asphalt pavement workers and related engineering applications, and the index requirements do not exceed the internal control value of the production plant.

\subsubsection{Density}

This technical index is designed to facilitate the habits of asphalt pavement workers and related engineering applications. Referring to the corresponding technical requirements of JTG F40 standard, the technical index requirements do not exceed the internal control value of the production plant.

\subsubsection{Residual Ductility after TFOT(or RTFOT)}

In order to ensure the reliable source and processing technology of hard asphalt for highway engineering, the ductility index $\left(25^{\circ} \mathrm{C}\right)$ should be retained, and the index should not exceed the internal control value of the production plant.

\subsubsection{Penetration}

Because the penetration of hard asphalt for highway engineering is lower, and the other properties of hard asphalt vary greatly with the change of penetration within the lower penetration range, the proposed standard is classified according to penetration grade, and each 10 penetrations are classified into four grades: 10-20, 20-30, 30-40, 40-50, with grading labels 15\#, 25\#, 35\#, and 45\#.

\subsubsection{Softening Point}

The high-temperature stability of hard asphalt for highway engineering is good. The softening point of different penetration ranges (ring and ball method) specified in this recommendation is not less than 60,57 , $55,50{ }^{\circ} \mathrm{C}$, not less than the corresponding index requirements of EU standards EN12591 and EN13924, higher than the index requirements of JTG F40, and suitable for more than $75 \%$ of domestic collected samples of hard asphalt (details in Table 1-4).

\subsubsection{Kinetic Viscosity $/ 60^{\circ} \mathrm{C}$}

High-temperature stability of hard asphalt is good. The Kinetic Viscosity of different penetration ranges at $60{ }^{\circ} \mathrm{C}$ is not less than 2000 Pa.s, 1000 Pa.s, 500 Pa.s, 300 Pa.s, higher than that of JTG F40, EN12591 and EN1392 4, and is suitable for more than $75 \%$ of domestic collected samples of hard asphalt (details in Table 1-4).

\subsubsection{Solubility}

The technical specifications are in accordance with the corresponding technical requirements of JTGF40 standard.

\subsubsection{Opening Flash Point}

The technical specifications are in accordance with the corresponding technical requirements of JTGF40 standard.

\subsubsection{Wax Content}

According to the research results of of China University of Petroleum and Research Institute of Highway of MOC [21-22], the influence of wax content in asphalt (pyrolysis, total wax content) on asphalt properties was studied in detail. Through research of the influence of wax content on softening point, penetration and ductility $\left(15^{\circ} \mathrm{C}\right)$ of asphalt, It is found that when the content of asphalt wax is less than $3 \%$, it has little effect on the properties of asphalt. According to the test results (Table 1-4 for details), the standard content of asphalt wax is set at $3 \%$.

\subsubsection{Weight Change After TFOT(or RTFOT)}

Compared with ordinary petroleum asphalt, the volatile components of hard asphalt for highway engineering are less, and the weight change after TFOT (or RTFOT) is less than that of other asphalt. This technical index is higher than the corresponding technical requirement of JTG F40 standard. The weight change of this recommended standard is not more than \pm 0 .) and meets condition of over $85 \%$ domestic collected samples of hard asphalt (details in Table 1-4). The weight change in JTG F40 is not more than \pm 0.8 .

\subsubsection{Residual Penetration Ratio After TFOT(or RTFOT)}

Compared with ordinary petroleum asphalt, for the penetration of hard asphalt is lower, then the change of penetration is smaller after TFOT (or RTFOT) aging. This technical index is higher than the corresponding technical requirements of JTGF40 standard. The recommended standard requires that Residual penetration ratio After TFOT (or RTFOT) should not be less than 65(details in Table 1-4). In JTG F40, the Residual penetration ratio After TFOT (or RTFOT) should be 58-65 according to different grades.

\section{Conclusions}

Based on the analysis of test results, by analyzing and referring to the relevant concepts and indexes of "Technical Specifications for Construction of Highway Asphalt Pavement" (JTG F40), European Union Standard EN13924 and European Union Standard EN12591, the recommended standards of this study are put forward. 
1. The definition of "hard asphalt for highway engineering " is proposed.

2. Proposed draft technical standards for hard asphalt for highway engineering are put forward, and the rationality and basis of the proposed standards are analyzed.

3. The draft proposal has been submitted to the highway administrative department for examination and approval.

\section{Author Contributions}

Conceptualization, J.L.; Data curation, J.L., S.Y.; Formal analysis, J.L., D.L.; Investigation, J.L., S.Y.; Methodology, J.L., S.Y.; Writing-original draft, S.Y, D.L.

\section{Funding}

This research was supported by Transportation Standardization Project of Ministry of Transport of China (JT2016-131)

\section{Acknowledgments}

The authors gratefully acknowledge the support of the Research Institute of Highway Ministry of Transport (RIOH) and China University of Petroleum.

\section{Conflicts of Interest}

The authors declare no conflict of interest.

\section{References}

1. ZHOU Ke-li, LU Kai-ji. Research status of hard asphalt and high modulus asphalt concrete abroad[J]. Journal of Highway and Transportation Research and Development, 2005.5, Vol22, No.5: 83-87

2. G.W.Maupin, Brink. Diefenderfer. Design of a High-Binder-High-Modulus Asphalt Mixture. Virginia Transportation Research Council, 2006, 12

3. Capitao, Silvino Dias, Picado-Santos, Luis. Assessing Permanent Deformation Resistance of High Modulus Asphalt Mixtures. Journal of Transportation Engineering, Vol (132), 2006

4. JEAN-FRANCOIS CORT. Development and Use of Hark-Grad Asphalt and of High-Modulus Asphalt Mixes in France. Perpetual Bituminous Pavement, Transportation Research Circular, No.503, December 2001

5. J P Serfass, et al. High Modulus Asphalt Mixes Laboratory Evaluation, Practical Aspect and Structual Design[R] .7th International Conference On Asphalt Pavement

6. P. Serfass, P. Bense, P. Pellevoisin. Properties Modulus Asphalt and New Developments of High Modulus Asphalt Concrete[R]. the Lecture series
Eight International Conference on Asphalt Pavements, Held at University of Washington,Seattle, 1997

7. Didier DESMOULIN, Philippe GIGUET, Patrice ORTEGA, et al. Comparative Experiment for PMB and Hard Bitumen on a Thin Anti Rutting Maintenance Treatme[R]. Vienna: 3rd Eurasphalt \&Eurobitume Congress, 2004

8. Anderson D.A, Christensen D.W, Bahia H. Physical Properties of Asphalt Cement and the Development of Performance-Related Specifications[J]. Assoc Asphalt Paving Technologists 1991, Vol60: 437-451

9. AO Qing-wen. Research on the pavement performance of High-Modulus Asphalt Mixture[D]. Changsha: Changsha University of Science and Technology, 2009

10. LIANG Chun-yu.Test Study of the 30\# Hard Grade Asphalt Used for Mid or Lower Surface Layer of Asphalt Pavement[D]. Changchun: Jilin University, 2007

11. LIU Feng. The Experimental Study on the Performance of Hard Asphalt and Asphalt Mixture[D]. Changchun: Jilin University, 2007

12. Jean-Francois Corte. Development and uses of hard-grade asphalt and of high-modulus asphalt mixes in franc[C]. Washington D C: Transportation Research Board, 2001: 12-31

13. SHA Qing-lin. Beijing: Premature Damage and Its Preservative Measures of Bituminous Pavement on Expressway[M]. China Communications Press, 2001: 402-403

14. LIU Chuang, WU Jian, LI Chang-hai. Study on Dynamic Shear Rheological Test of Low-grade Hard Asphalt[J]. Journal of China \& Foreign Highway, 2007.8, Vol27, No.4: 257-259

15. ZHANG Chun-hai. Experimental Study on High-temperature Performance of Rigid Asphalt[J]. Communications Standardization, 2008, No6: 37-39

16. ZHU Hao-ran, YANG Jun. Comparative Analysis of Rutting Resistance of Hard Asphalt[J]. Journal of China \& Foreign Highway, 2006, Vol26(No.6): 214-216

17. WANG Yu-shun. Study of Hard-grade Asphalt Mixes Performance[J]. Journal of Highway and Transportation Research and Development,2005.5, Vol22(No.5): 65-67

18. HUANG Tuo, QIAN Guo-ping, LI Hui-zhong. Experimental Study on Low Temperature Performance of No.30 Hard Asphalt and Its Mixture[J]. Journal of China \& Foreign Highway, 2008, Vol28(No.6): 224-226

19. CHENG Jian, XU Zhi-hong, HU Shang-jun. Study on Low Temperature Performance of Hard -grade Asphalt Mixture[J]. Highway Engineering, 2008, Vol.33(No1): 48-50, 90

20. ZHU Chun-yang, YANG Yi, LIU Xue-jian. Comparative analysis of rheological tests of curved beams with different labels of asphalt[J]. Journal of 
China \& Foreign Highway, 2007. 8, Vol27, No.4:289-291

21. SHEN Jin-an, et al. Tractical Technology of Heavy Traffic Highway Asphalt in High-grade Highway Engineering[R]. 1990

22. SHEN Jin-an, et al. Research on Pavement Performance of Asphalt and Asphalt Mixture for Highway[R]. 1996 